\title{
Selective inhibition of unfolded protein response induces apoptosis in pancreatic cancer cells
}

\author{
Wenwen Chien ${ }^{1, *}$, Ling-Wen Ding ${ }^{1, *}$, Qiao-Yang Sun ${ }^{1}$, Lucia A. Torres-Fernandez ${ }^{1}$, \\ Siew Zhuan Tan ${ }^{1}$, Jinfen Xiao ${ }^{1}$, Su Lin Lim ${ }^{1}$, Manoj Garg ${ }^{1}$, Kian Leong Lee ${ }^{1}$, Shojiro \\ Kitajima $^{1}$, Sumiko Takao ${ }^{1}$, Wei Zhong Leong ${ }^{1}$, Haibo Sun ${ }^{2}$, Itay Tokatly, ${ }^{1,3}$, Lorenz \\ Poellinger $^{1}$, Sigal Gery ${ }^{2}$, Phillip H. Koeffler ${ }^{1,2,4}$ \\ ${ }^{1}$ Cancer Science Institute of Singapore, National University of Singapore, Singapore \\ ${ }^{2}$ Cedars-Sinai Medical Center, UCLA School of Medicine, Los Angeles, California, USA \\ ${ }^{3}$ Cancer Research Center, Edmond and Lily Safra Children's Hospital, Sheba Medical Center, Israel \\ ${ }^{4}$ National University Cancer Institute, Singapore \\ * Co-first authors \\ Correspondence to: Wenwen Chien, email: csicw@nus.edu.sg \\ Keywords: UPR, pancreatic cancer, IREla
}

Received: April 15, $2014 \quad$ Accepted: May 30, $2014 \quad$ Published: June 1, 2014

This is an open-access article distributed under the terms of the Creative Commons Attribution License, which permits unrestricted use, distribution, and reproduction in any medium, provided the original author and source are credited.

\section{ABSTRACT}

Endoplasmic reticulum stress from unfolded proteins is associated with the proliferation of pancreatic tumor cells, making the many regulatory molecules of this pathway appealing targets for therapy. The objective of our study was to assess potential therapeutic efficacy of inhibitors of unfolded protein response (UPR) in pancreatic cancers focusing on IRE1a inhibitors. IRE1a-mediated XBP-1 mRNA splicing encodes a transcription factor that enhances transcription of chaperone proteins in order to reverse UPR. Proliferation assays using a panel of 14 pancreatic cancer cell lines showed a dose- and time-dependent growth inhibition by IRE1a-specific inhibitors (STF-083010, 2-Hydroxy-1-naphthaldehyde, 3-Ethoxy-5,6-dibromosalicylaldehyde, toyocamycin). Growth inhibition was also noted using a clonogenic growth assay in soft agar, as well as a xenograft in vivo model of pancreatic cancer. Cell cycle analysis showed that these IRE1a inhibitors caused growth arrest at either the G1 or G2/M phases (SU8686, MiaPaCa2) and induced apoptosis (Panc0327, Panc0403). Western blot analysis showed cleavage of caspase 3 and PARP, and prominent induction of the apoptotic molecule BIM. In addition, synergistic effects were found between either STF-083010, 2-Hydroxy-1-naphthaldehyde, 3-Ethoxy-5,6-dibromosalicylaldehyde, or toyocamycin and either gemcitabine or bortezomib. Our data suggest that use of an IRE1a inhibitor is a novel therapeutic approach for treatment of pancreatic cancers.

\section{INTRODUCTION}

Pancreatic ductal adenocarcinoma is one of the most common causes of death from cancer in both males and females.[1] More than $80 \%$ of patients are diagnosed at an advanced stage; and the average 5-year survival rate is less than $5 \%[1]$. One important feature of pancreatic cancer is the intense desmoplastic reaction around the tumors, which may impede delivery of therapeutic agents.[2] Gemcitabine and 5-fluorouracil are the standard treatment for advanced pancreatic cancers $[3,4]$ and a large number of gemcitabine-based combinations have been/are being tested.[5, 6] However, to a large extent, chemotherapy is ineffective and novel therapeutic options are direly needed.[7]

Endoplasmic reticulum (ER) is an organelle where cellular processes occur such as lipid synthesis, calcium storage, and appropriate processing of membrane and secreted proteins for maturation. Stress such as hypoxia or oxidative stress can cause accumulation of misfolded proteins in ER lumen, which triggers unfolded protein response (UPR) for either ER homeostasis or apoptosis. 
[8] Adapting to ER stress, cells activate a dynamic UPR mechanism that has three major signaling pathways: IRE1 $\alpha / \mathrm{XBP}-1$, ATF6, and PERK (pancreatic endoplasmic reticulum kinase). In response to ER stress, an initial cytoprotective mechanism is to release the ER chaperone GRP78 to facilitate protein folding. GRP78 is up-regulated in many cancers and is associated with poor survival.[911] However, when cells are unable to protect against ER stress, both intrinsic and extrinsic cell death pathways are activated, and severely damaged cells are removed.[12, 13] Additionally, after these sensor molecules (IRE1 $\alpha /$ XBP-1, ATF6, and PERK) are released from GRP78, cascades of UPR signaling are activated to balance survival against damage caused by ER stress. Of note, the tumor microenvironment for pancreatic cancers is extremely rich in stroma and is hypoxic and deficient in metabolites.[14] This predisposes these tumors to ER stress and UPR activation. The dynamics of UPR in these rapidly growing hypoxic tumors present potential therapeutic option.[15-17]

Therapy based on targeting GRP78 and other UPR signaling has been shown to inhibit growth of tumors.[18, 19] Drugs activating ER stress have been use for clinical treatment of cancers. Bortezomib, a proteosome inhibitor, induces ER stress and has therapeutic efficacy in multiple myeloma.[20, 21] Bortezomib also induces ER stress in pancreatic cancer cells and suppresses the UPR in these cancer cells.[22] Bortezomib also synergizes with cisplatin causing apoptosis of pancreatic cancer cells which may be mediated through enhanced ER stress via increased expression of CHOP/GADD153 and BiP/GRP78.[23]

Another approach to induce pancreatic cancer cell death is to inhibit the repair of UPR. For example, an IRE1 $\alpha$ inhibitor STF-083010 (STF) and its hydrolyzed product 2-Hydroxy-1-naphthaldehyde (HNA) block XBP-1 splicing, down-regulate XBP-1s expression and cause apoptosis in chronic lymphocytic leukemia (CLL) cells.[24] Furthermore, in multiple myeloma, inhibition of IRE1 $\alpha$-XBP-1s pathway by toyocamycin synergized with bortezomib to induce apoptosis.[25] In addition, high throughput screening identified salicylaldimine analogs as potent inhibitors of IRE1 $\alpha$ endonuclease activity.[26] One salicylaldimine analog, 3-Ethoxy-5,6dibromosalicylaldehyde (3ETH) inhibits XBP-1 splicing in myeloma cells both in vitro and in a murine model of ER stress in vivo.

As a result of these studies, we hypothesize that pancreatic cancers are under ER stress; and if we inhibit the protective mechanism of these cells against this stress by IRE1 $\alpha$ inhibitors, these pancreatic cancer cells will undergo apoptosis suggesting a novel therapeutic approach to this rapidly fatal disease.

\section{RESULTS}

\section{Anti-proliferative activity of IRE1 $\alpha$ inhibitors in pancreatic cancer cell lines}

We initially examined the ability of two IRE1 $\alpha$ inhibitors (STF and HNA) to inhibit the splicing of XBP-1 to XBP-1s in pancreatic cancer cell lines. Three pancreatic cancer cell lines (MiaPaCa2, Panc0403, SU8686) were pre-treated with tunicamycin to induce ER stress resulting in IRE $1 \alpha$ activation and splicing of XBP-1 to XBP-1s. STF and HNA suppressed the levels of splicing in a dosedependent manner (Fig.1). Since the inhibitory activity of STF in CLL was at the $50 \mu \mathrm{M}$ range,[24] we expanded our analysis to 6 pancreatic cancer cell lines (MiaPaCa2, Panc1005, SU8686, AsPc1, Panc0403, Panc0327) using $50 \mu \mathrm{M}$ of either STF or HNA. Other than Panc0327 cells, HNA was as potent as STF (Fig. 2A). The studies were then expanded and dose-responses of three different IRE1 $\alpha$ inhibitors (HNA, 3ETH, toyocamycin) were tested against a panel of 11 pancreatic cancer cell lines (Panc0203, Panc0327, Panc0403, SU8686, MiaPaCa2, Panc1, Panc0813, AsPC1, BxPc3, Panc0203, Panc1005) using an in vitro proliferation assay (MTT). Most of the pancreatic cancer cell lines were sensitive to these 3 IRE $1 \alpha$ inhibitors with a wide range of IC50s from 0.2 to $100 \mu \mathrm{M}$ (Fig. 2B). Notably, three pancreatic cancer cell lines (AsPc1, BxPc3, PL45) were resistant to HNA even at $100 \mathrm{uM}$, but were sensitive to $3 \mathrm{ETH}$ and toyocamycin; while Panc0813 was sensitive to HNA, but resistant to toyocamycin (Fig. 2B). Together, these data suggested that these inhibitors had different modes of activity or metabolism within these cancer cells.

Colony formation on plastic and soft agar was examined using two pancreatic cancer cell lines (MiaPaCa2, Panc0403) after 14 days exposure to either HNA, 3ETH, or toyocamycin. Toyocamycin decreased clonal growth in a dose-dependent manner by both assays (Figs. 3A \& 3B). Also, pancreatic cancer cells treated with HNA formed progressively fewer colonies on plastic (Fig. 3C), but to a lesser extent when assayed in soft agar (Fig. 3D). 3ETH was only examined in soft agar and also inhibited pancreatic clonal growth (Fig. 3E).

The anti-tumor activity of $3 \mathrm{ETH}$ on pancreatic cancer cell growth in vivo was examined using $\mathrm{BxPc} 3$ human tumors growing as xenografts in NOD/SCID mice. After tumors began their growth at day 4, mice were divided blindly into two groups and treated with either 20 $\mathrm{mg} / \mathrm{kg}$ of $3 \mathrm{ETH}$ or vehicle (PBS) alone for 4 weeks. At conclusion of the study, tumors were carefully dissected and weighed. Mean weight of tumors was significantly greater in the control mice than the cohort treated with 3ETH (Fig. 4, $P=0.0016$ ). We also tested HNA in vivo by growing Panc0403 human xenograft in NOD/SCID mice. 


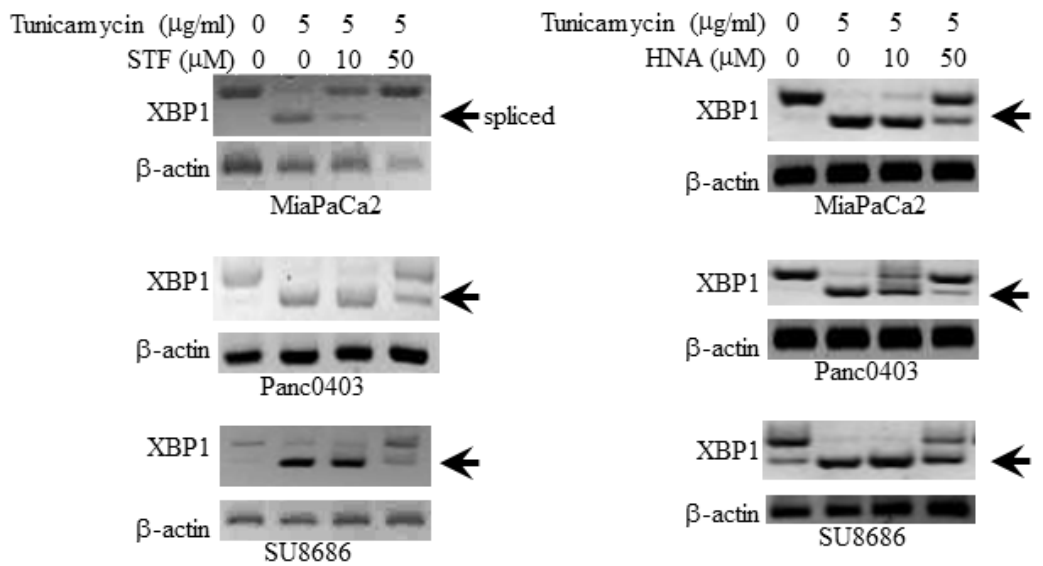

Figure 1: Suppression of tunicamycin-induced XBP-1 splicing by IRE1 $\alpha$ inhibitors. Three pancreatic cancer cell lines (MiaPaCa2, Panc0403, SU8686) were treated with either (A) STF or (B) HNA at either 10 or $50 \mu \mathrm{M}$ for $6 \mathrm{hr}$ after pre-incubation with tunicamycin $(5 \mu \mathrm{g} / \mathrm{ml}, 4 \mathrm{hr})$. XBP-1 splicing was detected by PCR as described in the Materials and Methods. Beta-actin was examined as a loading control. Arrow demarks spliced form of XBP-1.

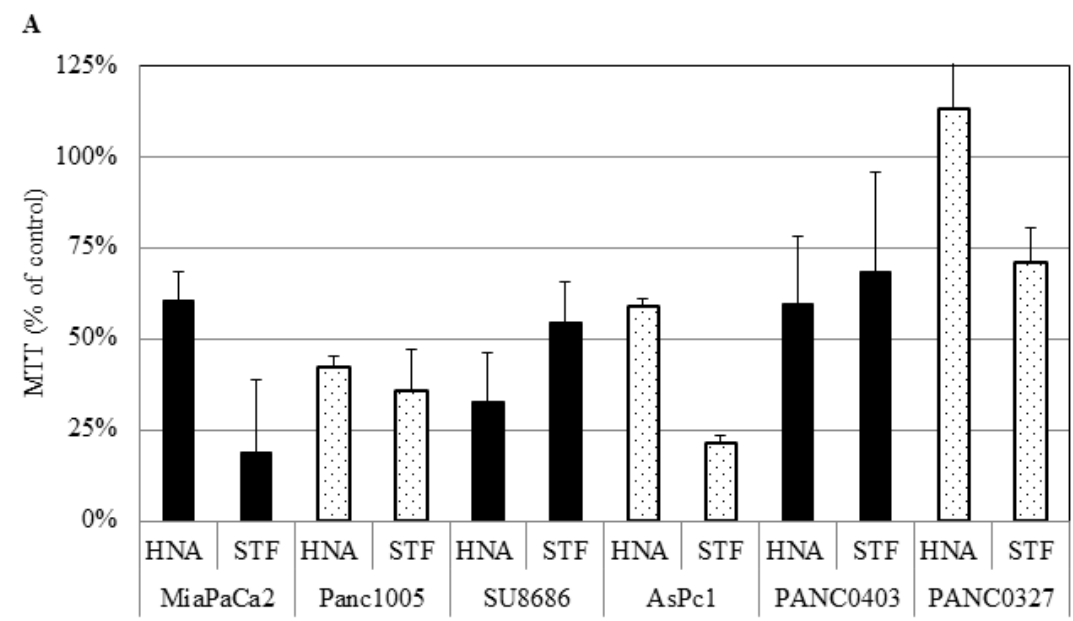

B

\begin{tabular}{|c|c|c|c|}
\hline Cell Line & $\begin{array}{c}\text { HNA } \\
(\mu \mathrm{M})\end{array}$ & $\begin{array}{c}3 \mathrm{ETH} \\
(\mu \mathrm{M})\end{array}$ & $\begin{array}{c}\text { Toyo } \\
(\mu \mathrm{M})\end{array}$ \\
\hline PANC0203 & 2.1 & 1.5 & n.d. \\
\hline PANC0813 & 24.1 & n.d. & R \\
\hline PANC0403 & 36.9 & 4.4 & 8.0 \\
\hline MiaPaCa2 & 56.1 & 0.4 & 2.7 \\
\hline SU8686 & 64.3 & 9.8 & 9.6 \\
\hline PANC1005 & 65.1 & 76.2 & 1.9 \\
\hline PANC0327 & 95.6 & 25.6 & 0.2 \\
\hline Panc1 & 98.6 & 23.5 & 1.9 \\
\hline AsPc1 & R & 6.3 & 0.5 \\
\hline BxPc3 & R & 1.1 & 0.2 \\
\hline PL45 & R & 67.4 & n.d. \\
\hline
\end{tabular}

Figure 2: Anti-proliferative activities of IRE1 $\alpha$ inhibitors. (A) The effect of STF $(50 \mu \mathrm{M})$ and HNA $(50 \mu \mathrm{M})$ on the cell growth of 6 pancreatic cancer cell lines compared to diluent treated controls (designated as 100\%). Pancreatic cancer cell lines were treated with indicated drugs for 3 days, and cell viability was determined by MTT assays. (B) IC50s of HNA, 3ETH, and toyocamycin (Toyo) were determined using a series of concentrations ( $1 \mathrm{nM}$ to $100 \mu \mathrm{M})$ of these drugs against a panel of pancreatic cancer cell lines using MTT assays. The IC50s were calculated with non-linear regression analysis using GraphPad Prism as described in Materials and Methods. R: Resistant at $>50 \mu \mathrm{M}$; n.d.: not done. 
The difference in tumor weight between HNA-treated xenograft and control was less remarkable $(p=0.29$, data not shown).

\section{Synergistic effects of IRE1 $\alpha$ inhibitors combined with other therapeutic reagents, as well as the effect of hypoxia}

Because the proteasome inhibitor bortezomib induces cell stress.[22] we investigated if the combination of IRE $1 \alpha$ inhibitors with bortezomib has the capacity to act synergistically. Four pancreatic cancer cell lines (Panc0403, Panc1005, BxPc3, MiaPaCa2) were treated with different combination of bortezomib (10 or 50 $\mathrm{nM})$ and STF $(10$ or $50 \mu \mathrm{M})$ (Fig. 5A). The normalized isobologram analysis demonstrated synergistic activity between $10 \mu \mathrm{M}$ STF and either 10 or $50 \mathrm{nM}$ bortezomib in all four cell lines (Fig. 5B, data points 1 and 2). Moreover, a higher concentration of STF $(50 \mu \mathrm{M})$ attained synergy after addition of bortezomib either at a concentration of 10 $\mathrm{nM}$ when tested against $\mathrm{BxPc} 3$ cells (Fig. 5B, data point 3 ), at a concentration of $50 \mathrm{nM}$ against Panc1005 cells (Fig. 5B, data point 4), and at either 10 or $50 \mathrm{nM}$ against Panc0403 cells (Fig. 5B, data points 3 and 4).

We further explored the combination of either HNA or toyocamycin with either bortezomib, 17-DMAG (heat shock protein inhibitor, 17-Dimethylaminoethylamino17-demethoxygeldanamycin), gemcitabine (frequently used therapeutic agent), or dasatinib (src kinase inhibitor, FDA-approved for treatment of pancreatic cancer) in pancreatic cancer cells (Panc0403, SU8686, MiaPaCa2). Combination index (CI) was calculated and the CI plots showed synergistic activity of either HNA or toyocamycin combined with these drugs at concentrations shown (Fig.
$6)$.

The fact that pancreatic tumors are usually densely embedded within stromal cells creating a hypoxic environment, we examined if the IRE1 $\alpha$ inhibitor (toyocamycin) combined with bortezomib had the same efficacy at normoxic $\left(21 \% \mathrm{O}_{2}\right)$ versus hypoxic $\left(2 \% \mathrm{O}_{2}\right)$ conditions. Two cell lines (MiaPaCa2, AsPc1) were treated with the combination of toyocamycin $(25,250$, or $2500 \mathrm{nM})$ and bortezomib $(1.6,16$, or $166 \mathrm{nM})$ (Fig. $7 \mathrm{~A})$. CI plots showed that irrespective of the oxygen environment, synergistic growth inhibition prevailed against pancreatic cancer cells (Fig. 7B). The CI values were below 1 at the combination of $25 \mathrm{nM}$ toyocamycin and $1.6 \mathrm{nM}$ bortezomib (Fig. 7B, data point 1), or $250 \mathrm{nM}$ toyocamycin and $16 \mathrm{nM}$ bortezomib (Fig. 7B, data point 2).

\section{Mechanisms underlying the anti-proliferative effects of IRE1 $\alpha$ inhibitors against pancreatic cancer cells:}

Pancreatic cancer cells (Panc0403) cultured with HNA (10 and $50 \mu \mathrm{M}, 24 \mathrm{hr}$ ) had a substantial pre-G1 fraction after exposure to $10 \mu \mathrm{M}$ HNA ( $25 \%$, apoptotic cells) and $50 \mu \mathrm{M}$ HNA (36\%, apoptotic cells) (Fig. $8 \mathrm{~A})$. Testing of two other pancreatic cancer cell lines (MiaPaCa2, Panc0327) treated with HNA $(10 \mu \mathrm{M}, 24 \mathrm{hr})$ also induced an increase of the pre-G1 fraction $(23 \%$ and $28 \%$, respectively, Fig $8 \mathrm{~B}$ ).

We wondered if these IRE1 $\alpha$ inhibitors also effected mitochondria. The assay, TMRE, detects mitochondrial membrane depolarization. Panc0403 cells treated with increasing concentrations of either HNA $(0.1-10 \mu \mathrm{M})$ or toyocamycin $(1,5 \mu \mathrm{M})$ showed decreasing mitochondrial
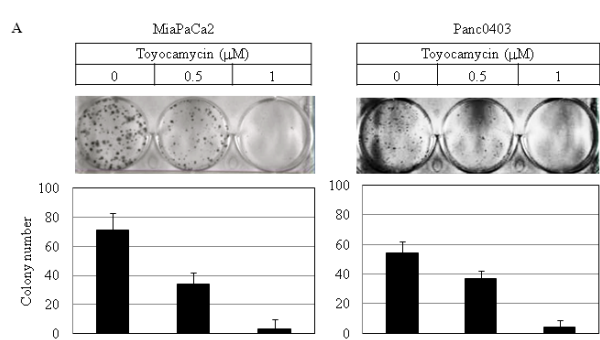

B

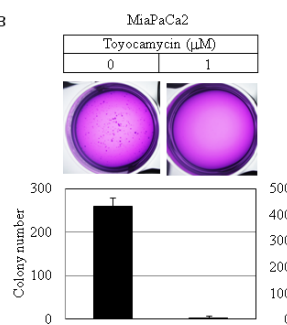

Panc0403

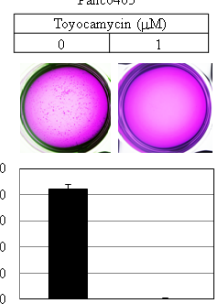

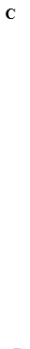

$\mathbf{D}$
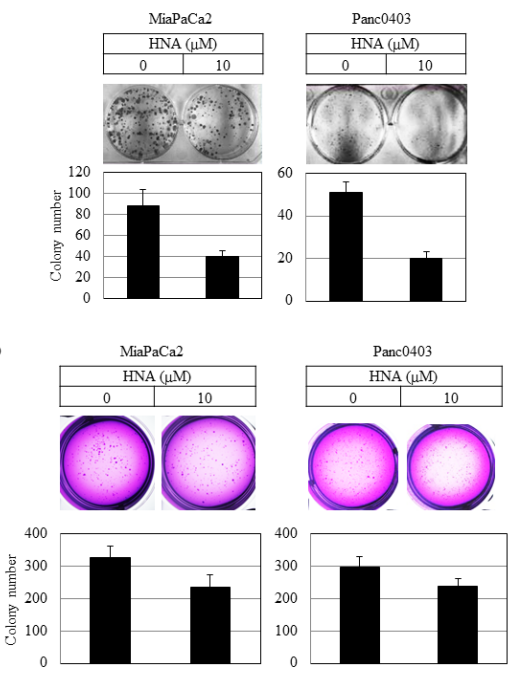
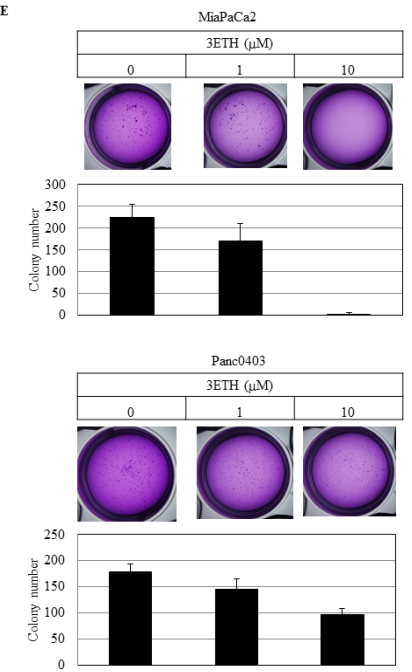

Figure 3: Colony formation of pancreatic cancer cells. Pancreatic cancer cell lines (MiaPaCa2, Panc0403) were treated with drugs (toyocamycin $[0.5,1 \mu \mathrm{M}]$, HNA $[10 \mu \mathrm{M}]$ or $3 \mathrm{ETH}[1,10 \mu \mathrm{M}]$ ) for 14 days; and colony formation on plastic (A, C) and soft agar (B, D, E) was assessed. Representative plates are shown. Number of colonies on each plate was calculated with ImageJ; and numbers shown are average of duplicates from two independent experiments. 

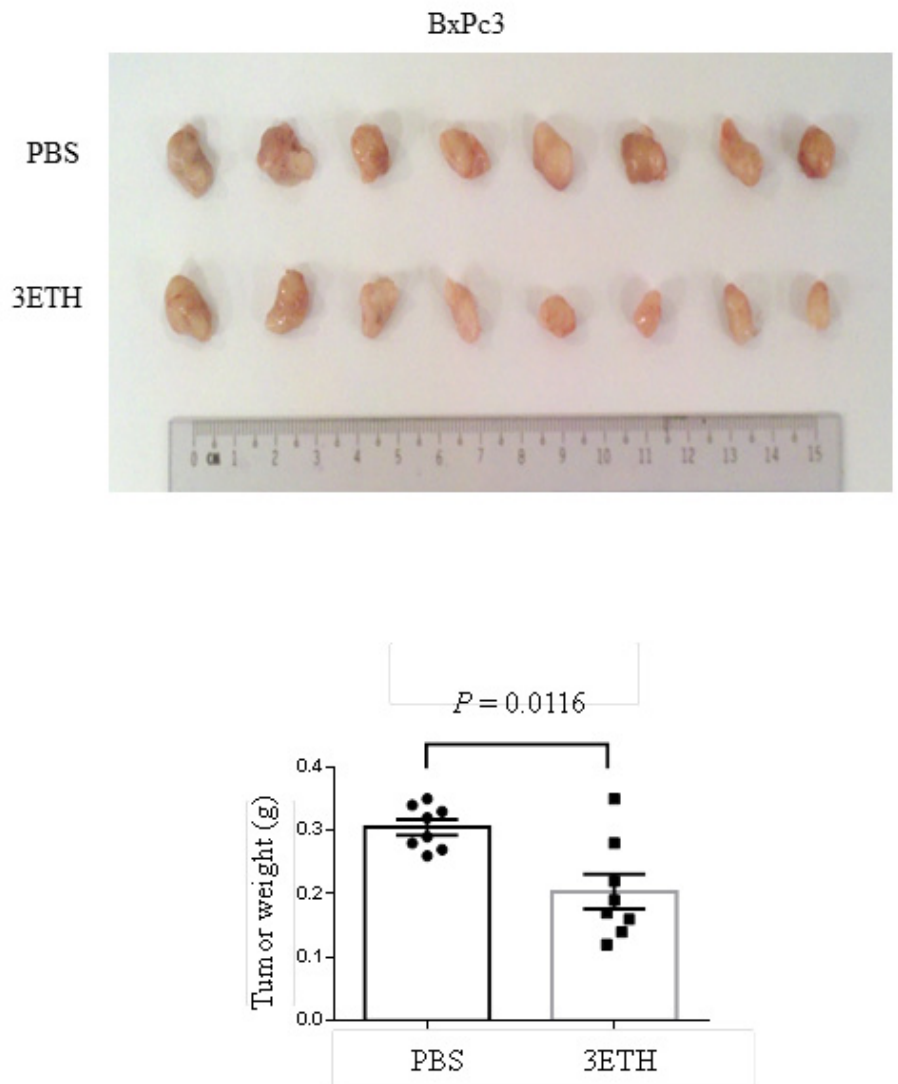

Figure 4: Effect of 3ETH on growth of BxPc3 human pancreatic cancer xenografts in NOD/SCID mice. Two million $\mathrm{BxPc} 3$ cells were subcutaneously injected, and drug treatment was started at day 4. 3ETH was injected intraperitoneally three times a week for 4 weeks. Tumors were harvested and weights were measured. Top panel: tumors; Bottom panel: weights.

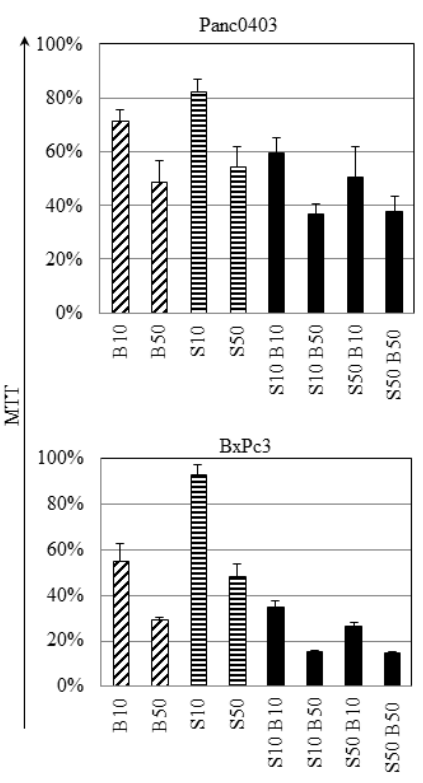

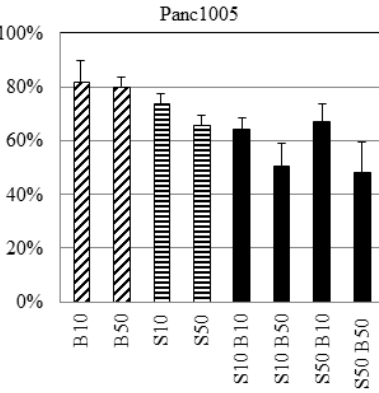

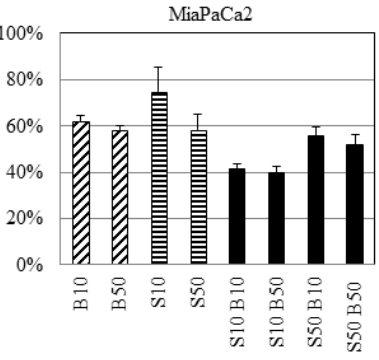

в
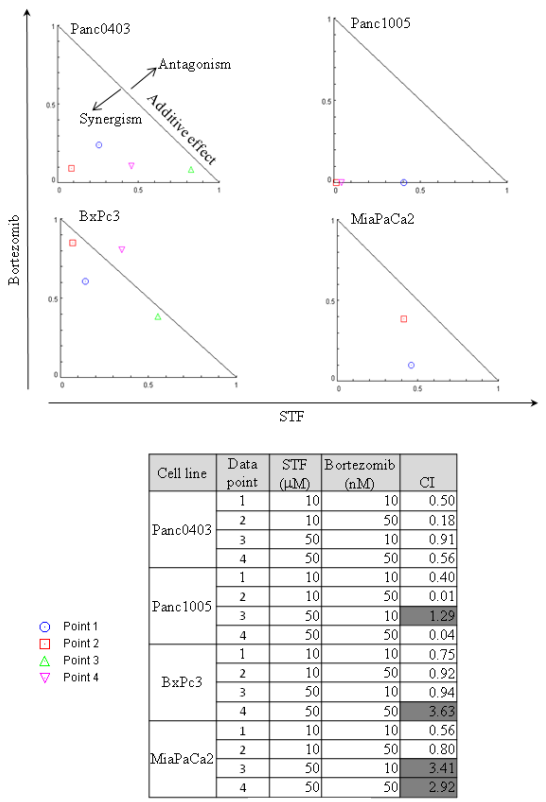

Figure 5: IRE1 $\alpha$ inhibitor STF and proteasome inhibitor bortezomib synergistically inhibited the in vitro proliferation of pancreatic cancer cells. (A) Four pancreatic cancer cell lines (Panc0403, Panc1005, BxPc3, MiaPaCa2) were cultured at different concentrations of drugs, and cell viability was measure by MTT assays. Drugs used were bortezomib (B10, B50: bortezomib 10, $50 \mathrm{nM}$ ) and STF (S10, S50: STF 10, $50 \mu \mathrm{M}$ ). (B) Isobologram analysis of combination of STF with Bortezomib from A (Panel B, top). CalcuSyn software was used to produce normalized isobolograms; and values below threshold line indicate synergistic combination; gray shaded boxes indicate non-synergistic combination $(\mathrm{CI}>1)$ (Panel B, bottom). 


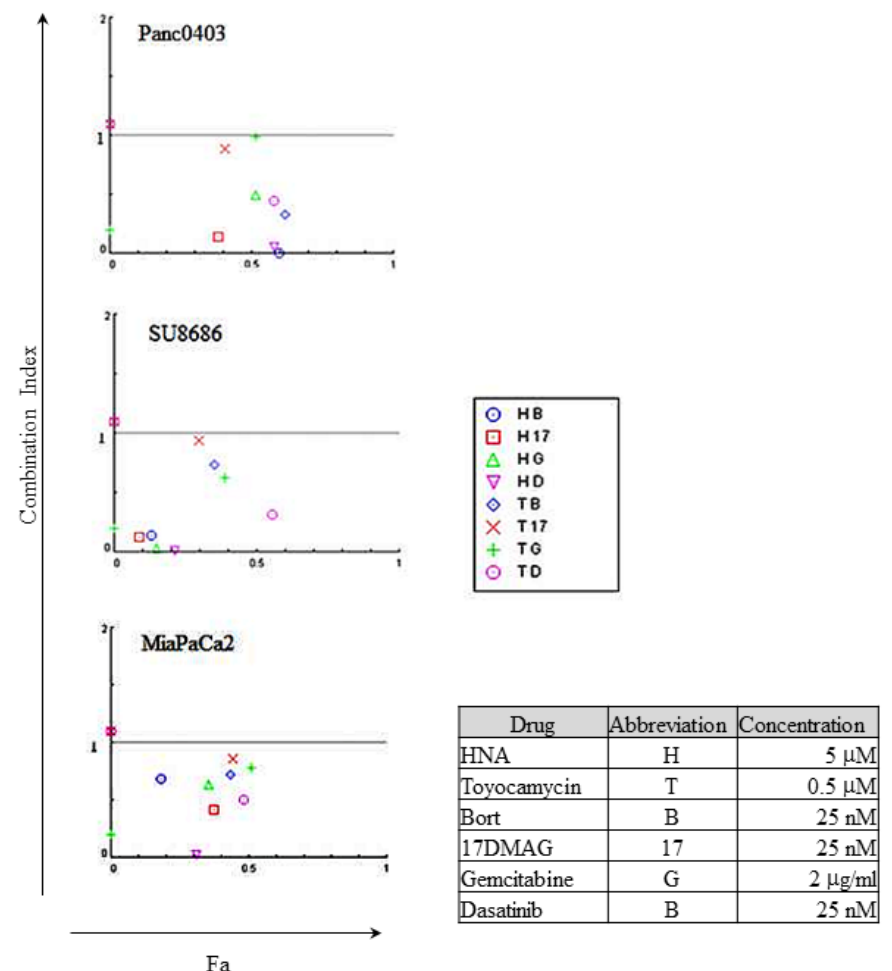

Figure 6: Combination index plot of HNA and toyocamycin with four different drugs (bortezomib, 17-DMAG, gemcitabine, dasatinib). Three pancreatic cancer cell lines (Panc0403, SU8686, MiaPaCa2) were incubated with drugs for 48h at concentrations indicated in Figure. Combination index (CI) plots were calculated with Calcusyn software as described in Materials and Methods. CI $<1$ indicates synergism between two drugs. Fa: the fraction that is affected or inhibited. B: bortezomib; 17: 17-DMAG; G: gemcitabine; D: dasatinib.

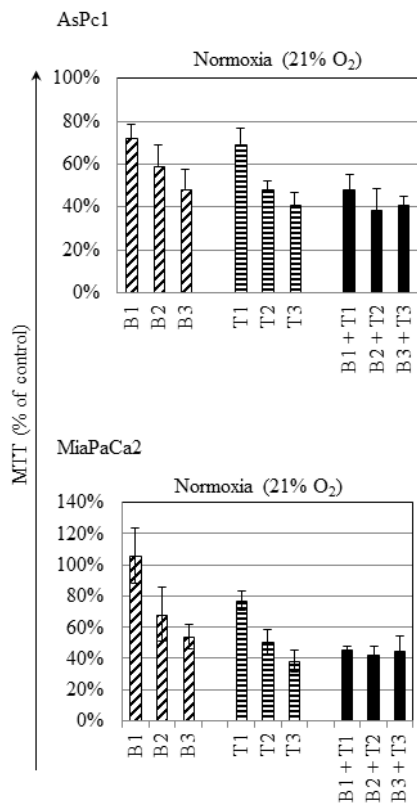

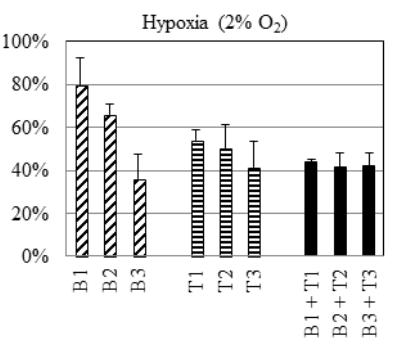

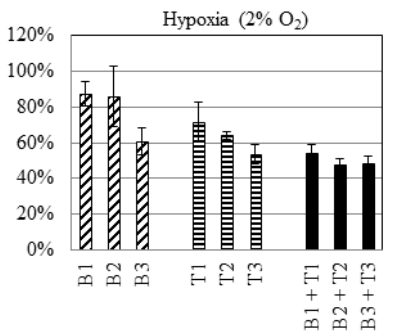

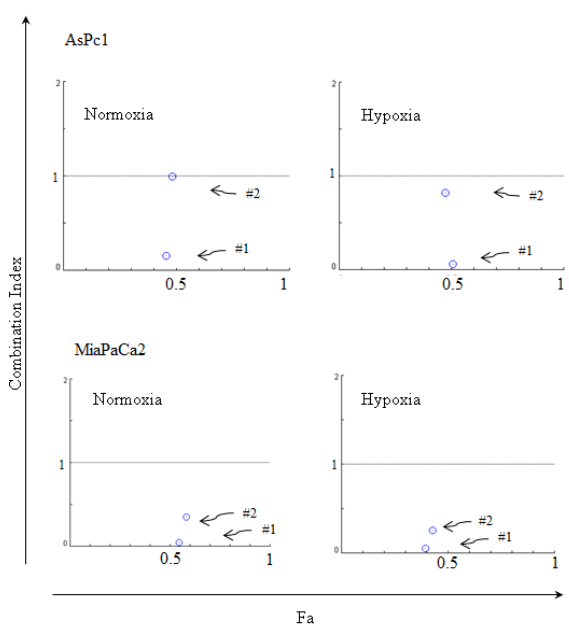

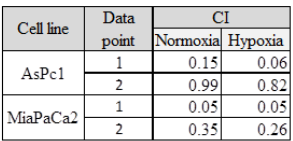

Figure 7: Synergistic effect when cultured in hypoxia. Two pancreatic cancer cell lines (AsPc1, MiaPaCa2) were cultured in either normoxic $\left(21 \% \mathrm{O}_{2}\right)$ or hypoxic $\left(2 \% \mathrm{O}_{2}\right)$ conditions with different drug combinations for $48 \mathrm{hr}$. (A) Cell viability was measured by MTT assays. Drugs tested were bortezomib (B1: $1.6 \mathrm{nM} ; \mathrm{B} 2: 16 \mathrm{nM} ; \mathrm{B} 3: 166 \mathrm{nM})$ and toyocamycin (T1: $25 \mathrm{nM} ; \mathrm{T} 2: 250 \mathrm{nM} ; \mathrm{T} 3: 2500 \mathrm{nM})$. (B) Combination index (CI) was calculated as described in Materials and Methods. $\mathrm{CI}<1$ indicates synergism between two drugs. Fa: affected fraction. Data point 1: 1.6 nM bortezomib, $25 \mathrm{nM}$ toyocamycin); Data point 2: $16 \mathrm{nM}$ bortezomib, $250 \mathrm{nM}$ toyocamycin. 
membrane potential by either flow cytometer (Fig. 9A) or fluorescence microplate reader (Fig. 9B). Furthermore, two other pancreatic cancer cell lines (Panc1, Panc0327) treated with HNA $(10,50 \mu \mathrm{M})$ or toyocamycin $(1,5$ $\mu \mathrm{M})$ also displayed markedly decreased mitochondrial membrane potential (Fig. 9B).

Expression levels of proteins related to cellular apoptosis were examined in two pancreatic cancer cell lines (Panc0403, MiaPaCa2) after treatment with either HNA $(10 \mu \mathrm{M})$ or toyocamcin $(1 \mu \mathrm{M})$. Protein levels of the anti-apoptotic protein Bcl-2 decreased and the proapoptotic protein BIM increased (Fig. 10A). Both long and short forms of BIM were induced in Panc0403 cells, but only the long form was induced in MiaPaCa2 cells (Fig. 10A). Total caspase 3 protein levels decreased and cleaved PARP levels increased (Fig. 10A). Since BIM was markedly induced after HNA treatment, pancreatic cancer cells (MiaPaCa2, Panc0403) were infected with shRNA targeting BIM to examine the role of BIM in mediating the anti-proliferative activity of HNA. Two stable clones were selected from both cell lines infected with shBIM (shBIM1, shBIM2). Based on the real-time PCR, expression levels of BIM mRNA were similarly silenced in all stable pancreatic cancer cell lines containing shBIM (Fig. 10B), These experimental clones and control clone

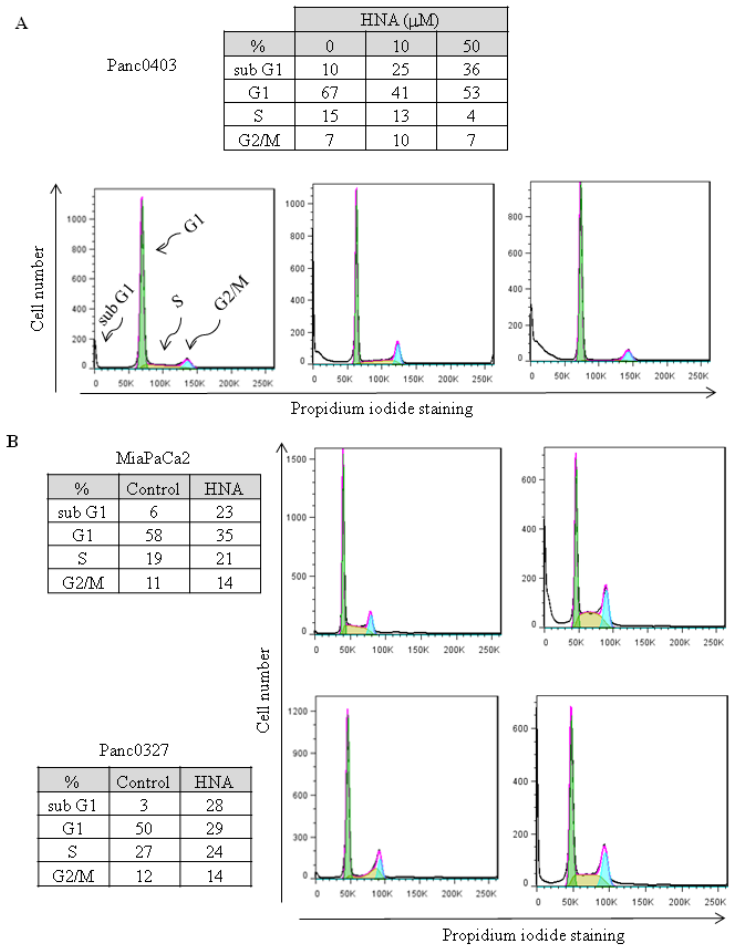

Figure 8: Cell cycle analysis. Three pancreatic cancer cell lines (Panc0403, MiaPaCa2, Panc0327) were treated with HNA for $24 \mathrm{~h}$; and DNA fractions were then analysed with flow cytometry. Cell cycle was fitted with Dean-Jett-Fox model in FlowJo as described in Materials and Methods. For each cell line, representative results from three independent experiments are shown. (one clone from scrambled shRNA - shCON) were treated with $\operatorname{HNA}(1,10 \mathrm{uM})$, and cell viability were determined by MTT assays. Knockdown of BIM caused the pancreatic cancer cells to become more resistant to killing by HNA with Panc0403 with stable shBIM2 having the greatest resistance to HNA ( $p=0.038$, Fig. 10B). This suggests pancreatic cancer cell death by IRE1 $\alpha$ inhibitors is partially attributed to induction of BIM.

Since BIM can be transcriptionally activated by CHOP in UPR,[27] we examined CHOP mRNA levels after treatment with IRE1 $\alpha$ inhibitors in four pancreatic cancer cell lines (MiaPaCa2, Panc0403, SU8686, AsPc1). As expected, pre-treatment with tunicamycin induced CHOP expression which was further increased by the addition of either STF or HNA (Fig. 11A).

DNAJB9 is one of the UPR target genes which transcriptionally activated by XBP-1s.[28] In pancreatic cancer cells treated with either STF or HNA, levels of DNAJB9 mRNA were suppressed after initial induction
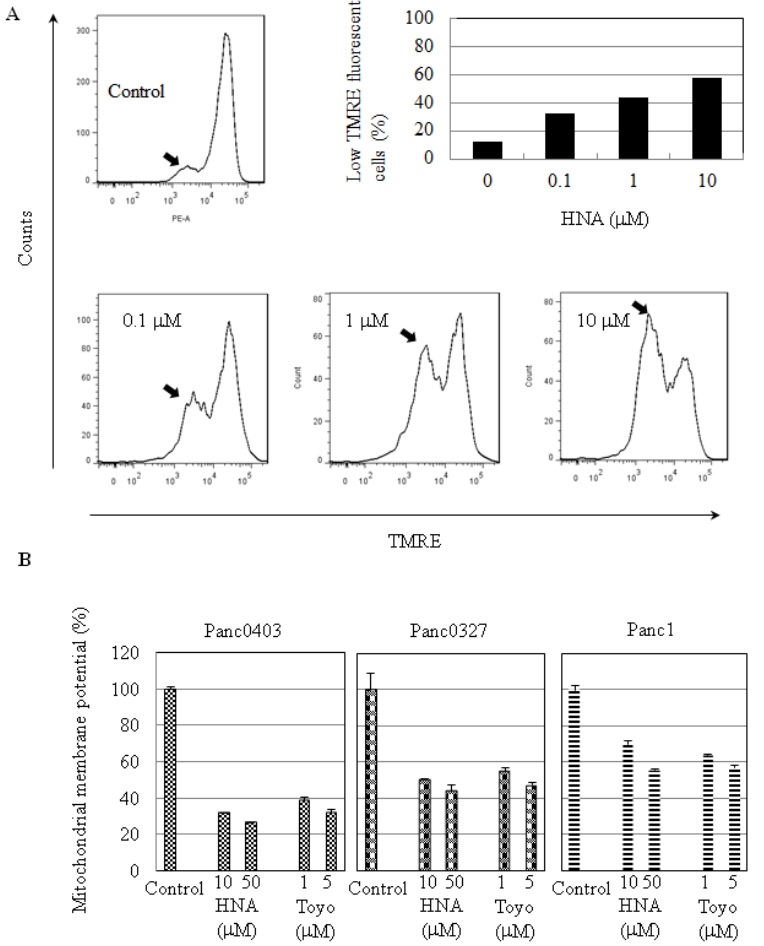

Figure 9: Mitochondrial membrane depolarization induced by HNA. (A) Panc0403 pancreatic cancer cells were treated with HNA at $0.1,1,10 \mathrm{uM}$ for $24 \mathrm{hr}$, and mitochondrial membrane potential was analysed by TMRE (tetramethyrhodamine ethyl ester percholarte) fluorescence. Histograms show the amount of TMRE sequestered by mitochondrial membrane. Low TMRE fluorescence (arrow) indicates decreased membrane potential. From the histogram, the portion of cells with low TMRE fluorescence (membrane potential) is summarized in the bar graph. (B) Three pancreatic cancer cell lines (Panc1, Panc0327, Panc0403) were treated with either HNA or toyocamycin at different concentrations for $24 \mathrm{hr}$ and uptake of TMRE fluorescence by the cells was detected by a fluorescent plate reader. Each sample was run in duplicate, and the data represent the mean $\pm \mathrm{SD}$ of two separate assays. 
by tunicamycin (Fig. 11B). We also examined the transcription factor ATF4 of the PERK branch of UPR, and found that expression levels of ATF4 were not affected in two cell lines (MiaPaCa2, Panc0403), but were induced substantially in two other (SU8686, AsPc1) after either STF or HNA treatment (Fig. 11C). This suggests differential cellular response to these compounds.

We also examined levels of several other key proteins associated with cellular ER stress and cell growth. Phosphorylated Erk and its upstream regulator PDK1, were down-regulated and phosphorylation of JNK was increased after HNA treatment in two of the pancreatic cancer cell lines (Fig. 12A). A reactive oxygen species (ROS) sensor thioredoxin binding protein (TXNIP) and thioredoxin (TXN) were evaluated in pancreatic cancer cells (Panc0403, MiaPaCa2) following treatment with either HNA or 3ETH. Messenger RNA expression levels of TXNIP were up-regulated while TXN levels were down-regulated by HNA and 3ETH (Fig. 12B).

\section{DISCUSSION}

The ER plays an important role in the secretory pathway in which proteins undergo post-translational modification. Overload of nascent proteins or mis- and un-folded proteins induces ER stress and activates UPR. Studies have found that a histone deacetylase inhibitor such as panobinostat induces apoptosis in hepatocellular carcinoma associated with up-regulation of ER stress markers (Grp78, eIf2a, and XBP-1).[29] Treatment of chronic lymphocytic leukemia and multiple myeloma

A

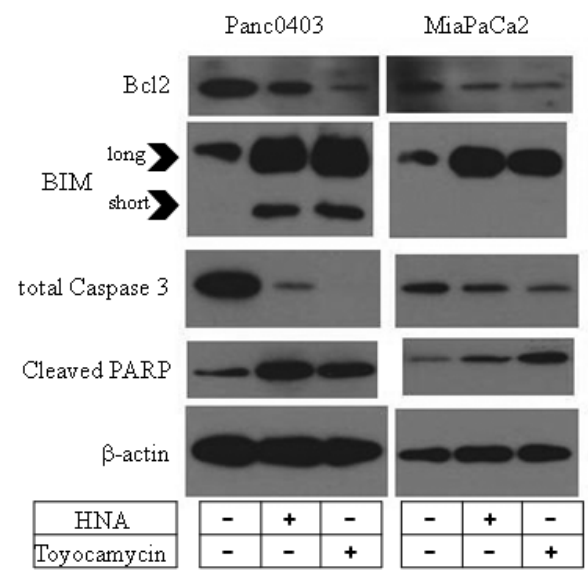

B
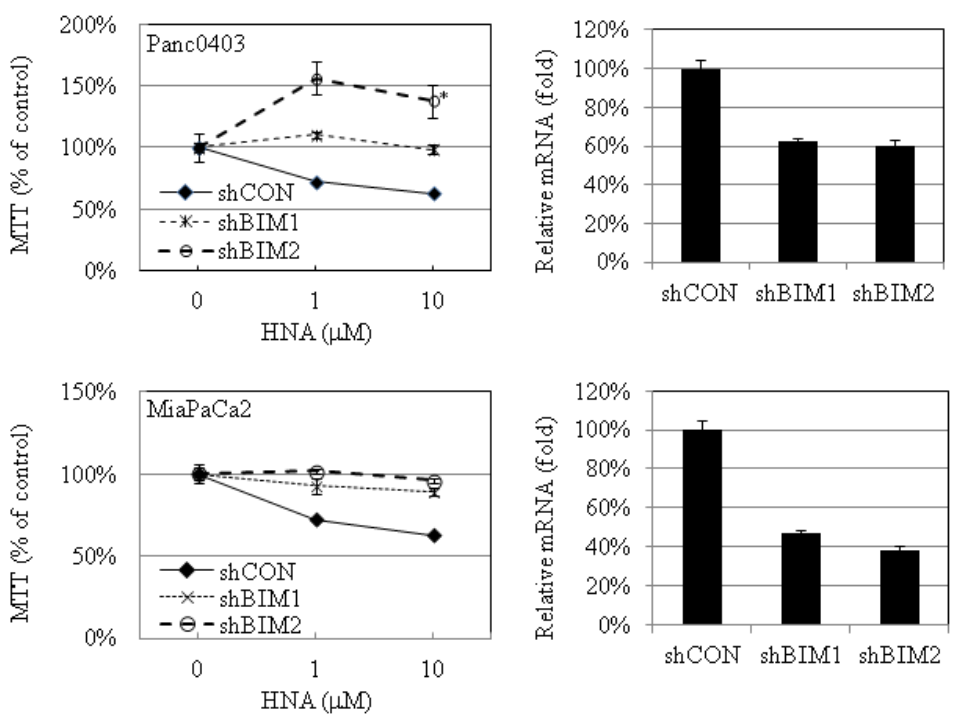

Figure 10: IRE1 $\alpha$ inhibitor treatment: Apoptosis-related proteins in pancreatic cancer cells. (A) Western blot analysis of apoptosis-related proteins in 2 pancreatic cancer cell lines (Panc0403, MiaPaCa2) after treatment with either HNA (10 $\mu \mathrm{M})$ or toyocamycin $(1 \mu \mathrm{M})$ for $24 \mathrm{~h}$. Beta-actin was loading control. Representative blots were from two independent experiments. (B) MTT assays of pancreatic cancer cell growth after knockdown of BIM. Two clones of pancreatic cancer cell lines stably infected with shRNA targeting BIM (shBIM1, shBIM2) were treated with HNA $(1,10 \mathrm{uM})$ for $48 \mathrm{hr}$, and MTT assays was used to compared cell viability in experimental (shBIM1, shBIM2) versus scrambled shRNA control (shCON). *: $p=0.038$ (left panel). Percent knock-down of BIM by shBIM1 and shBIM2 is shown on right panel. 

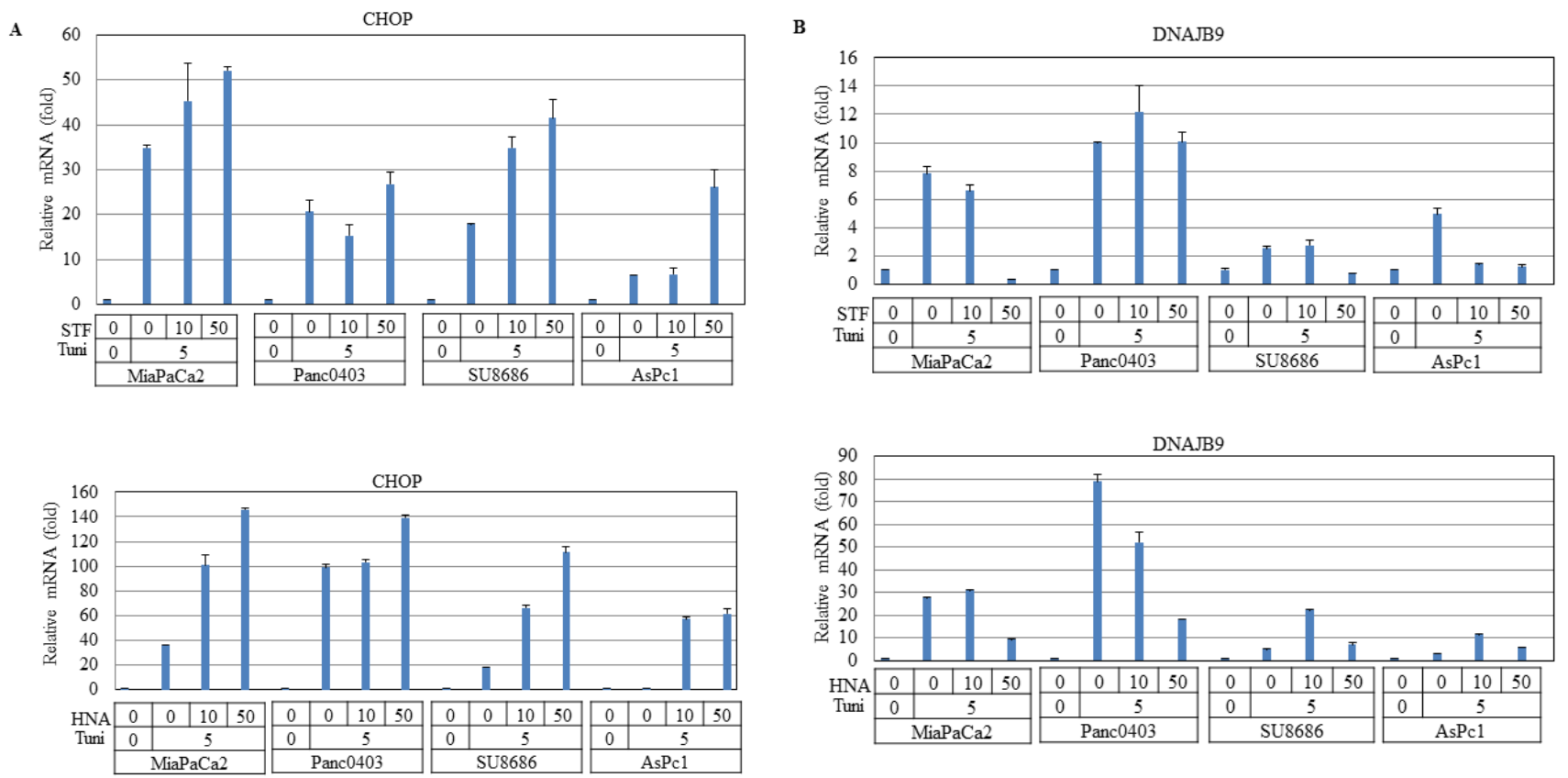

C

ATF4

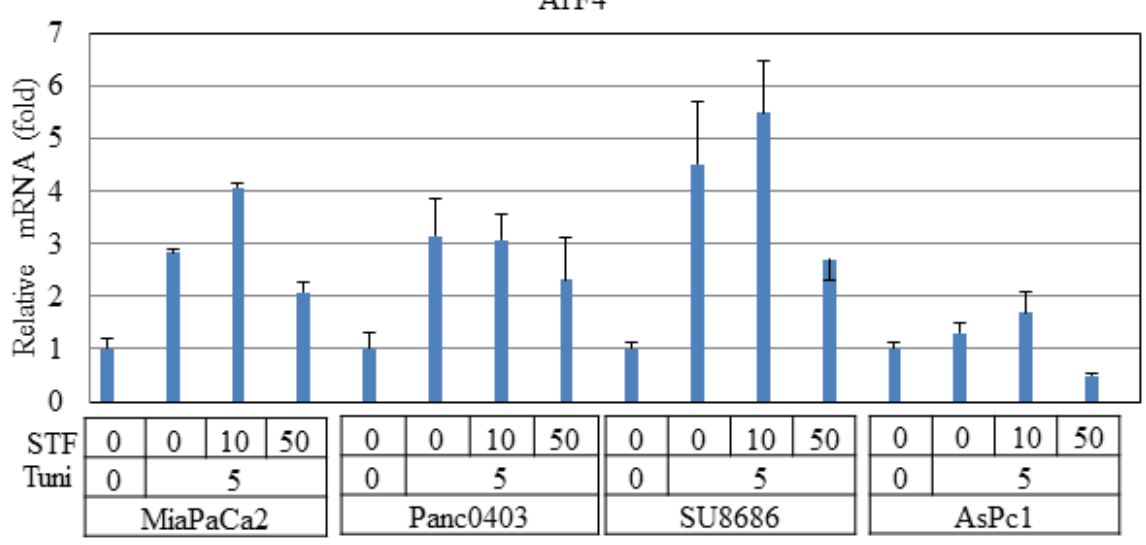

ATF4

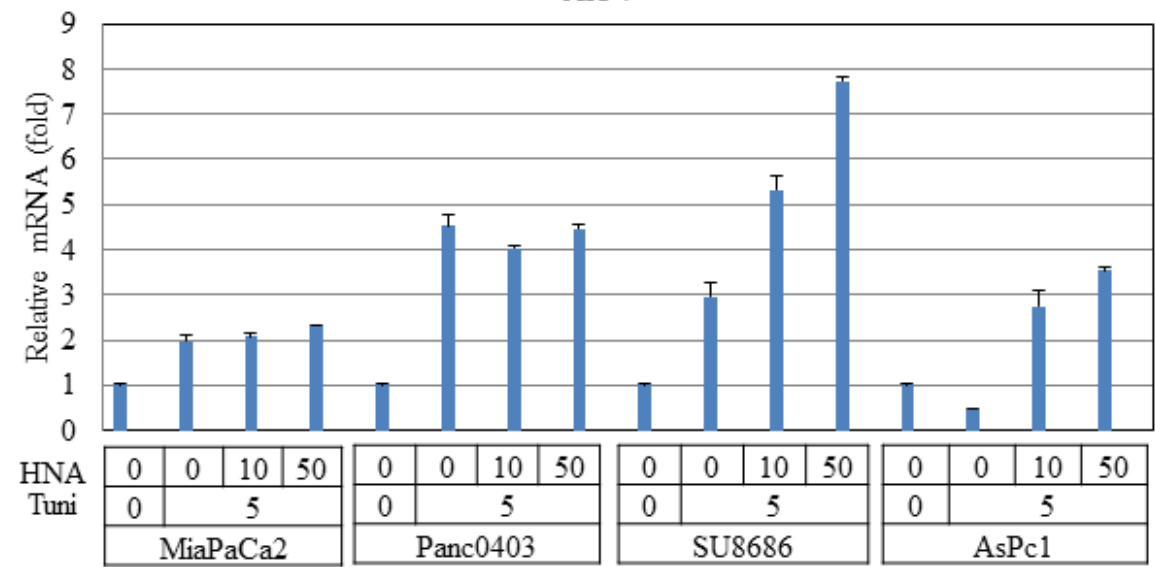

Figure 11: Effect of STF or HNA on expression of UPR target genes in pancreatic cancer cells. Messenger RNA expression levels of (A) CHOP (B) DNAJB9 (C) ATF4 were examined by real-time PCR in four pancreatic cancer cells (MiaPaCa2, Panc0403, SU8686, AsPc1) after treatment with either STF or HNA $(10$ or $50 \mu \mathrm{M}, 6 \mathrm{hr})$. Tuni: tunicamycin $(5 \mu \mathrm{g}, 4 \mathrm{~h})$ was added as a pre-treatment. Results are means $\pm \mathrm{SD}$ of two independent experiments done in triplicates. 
cells with brefeldin A, an inhibitor of ER to Golgi protein transport cause a decrease in VEGF secretion and abnormal ER swelling; and subsequently activation of caspases, and cell death.[30] UPR is an intricate process in the face of cellular ER stress. Initial UPR attempts to restore ER homeostasis is by temporarily suspending protein translation. In addition, ER stress stimulates IRE1 $\alpha$ to splice XBP-1 mRNA resulting XBP-1s.[31] XBP-1s becomes an active transcription factor enhancing synthesis of genes involved in protecting the cells from changing levels of ER stress and unfolded poteins.

Pancreatic cancer remains a catastrophic disease with a 5-year survival rate of 5\%. First-line therapy with either gemcitabine or gemcitabine-based chemotherapeutic combinations provides small clinical improvements, but new effective treatment options are clearly needed. We examined the effect of four IRE $1 \alpha$ inhibitors (STF, HNA, $3 \mathrm{ETH}$, toyocamycin) against a panel of 11 pancreatic cancer cell lines using a MTT liquid culture assay and found a wide range of drug sensitivities, ranging from 2 to $100 \mu \mathrm{M}$. We then employed a much more sensitive assay, clonogenic growth in soft agar which showed that these pancreatic cancer cells were very sensitive to growth inhibition by IRE $1 \alpha$ inhibitors. Importantly, the IRE1 $\alpha$ inhibitor (3ETH) also decreased the proliferation of human pancreatic cancer xenografts growing in vivo (70\% growth compared to control cells, $p=0.0116$ ). The data suggest IRE1 $\alpha$ inhibitors significantly reduce growth of pancreatic tumors.

In further experiments, synergism was found by combining IRE1 $\alpha$ inhibitors with FDA-approved agents such as either bortezomib, 17-DMAG, gemcitabine, or dasatinib. Our findings indicate that selective inhibition of ER stress by IRE1 $\alpha$ inhibitors could curb pancreatic cancer cell growth in drug combination. Pancreatic cancers are extremely rich in stromal cells and are hypovascular, suggesting that the cancer cells are hypoxic. In view of this landscape, we explored the drug combination of bortezomib and toyocamycin in hypoxic conditions. Synergism was sustained when tested in hypoxic condition $\left(2 \% \mathrm{O}_{2}\right)$.

Our mechanistic studies of how IRE1 $\alpha$ inhibitors decrease pancreatic cancer cell proliferation found these agents robustly induced prominent levels of BIM. In contrast, silencing of BIM rendered pancreatic cancer cells less sensitive to killing by IRE $1 \alpha$ inhibitors. Attenuation of cell death by BIM knockdown was partial and in some clones not statistically significant. This may be due to incomplete silencing of BIM as well as involvement of additional pathways important in cell death mediated by IRE1 $\alpha$ inhibitors. We found the extra-long form of BIM (BIM-EL) was induced in two pancreatic cancer cell lines (Panc0403 and MiaPaCa2). The pro-apoptotic BIM-EL can be phosphorylated and subsequently degraded in the proteasome when ERK signaling is activated.[32, 33] In addition, phosphorylation of BIM by ERK reduces its pro-apoptotic activity by preventing binding of BIM to BAX.[34] On the other hand, phosphorylation of BIM by JNK at a different site activates the apoptotic activity of BIM and induces BAX-dependent apoptosis[35]. Our treatment of pancreatic cancer cells with IRE1 $\alpha$ inhibitors decreased levels of phosphorylated ERK and increased levels of phosphorylated JNK. These data suggest upon treatment with IRE1 $\alpha$ inhibitors, BIM was activated by JNK phosphorylation as well as heterodimerization with BAX to promote cell apoptosis of pancreatic cancer cells.

CHOP is another primary target of induction of cell death after stress activation of ER.[27] It can be activated transcriptionally through all three branches of UPR: IRE1 $\alpha$, PERK/ATF4, and ATF6.[36] Treatment of pancreatic cancer cells with IRE1 $\alpha$ inhibitors still caused induction of CHOP, suggesting CHOP was activated through ATF4 and ATF6. Our real-time PCR results suggest the ATF6 pathway was stimulated. Also, a previous study showed that through DR5 activation, the JNK pathway induced CHOP and the cell death pathway. [37] As mentioned above, we showed that phosphorylation of JNK was up-regulated after exposure of the pancreatic cancer cells to an IRE1 $\alpha$ inhibitor. This suggests that pancreatic cancer cell death by IRE $1 \alpha$ inhibitors may also involve phosphorylation levels of JNK, which induces CHOP.

Examination of mitochondrial membrane potential revealed pancreatic cancer cell death caused by IRE1 $\alpha$ inhibitors may also involve the intrinsic mitochondriamediated apoptosis pathway. Mitochondrial membrane potential was lost when pancreatic cancer cells were treated with IRE1 $\alpha$ inhibitors. Loss of mitochondrial membrane potential can lead to swelling of mitochondrial membrane and release of cytochrome $\mathrm{C}$ to cytosol, which activates caspase 3 and apoptosis.[38] Congruent with activation of this pathway, cleavage of caspase 3 and cell death occurred after exposure of the pancreatic cancer cells to IRE1 $\alpha$ inhibitors.

ROS scavenger TXN and its interacting protein TXNIP play an important role in regulating oxidative stress[39] and over-expression of TXNIP will induce G0/ G1 cell cycle arrest.[40] Crosstalk between ER stress and ROS has previously been suggested.[41, 42] Our data showed that TXNIP was induced and TXN was reduced after pancreatic cancer cells were treated with IRE1 $\alpha$ inhibitors. These results suggest that IRE1 $\alpha$ inhibitors may induce ROS helping to mediate cell death.

Based on our findings, we proposed a scheme to elucidate the anti-proliferative activities of IRE1 $\alpha$ inhibitors (STF, HNA, 3ETH, toyocamycin) in pancreatic cancer cells. IRE1 $\alpha$ inhibitors caused overwhelming ER stress, which induced CHOP expression and subsequently BIM activation (Fig. 13, step 1). Perturbation of ER stress may regulate ROS through up-regulation of TXNIP and subsequently help trigger apoptosis by modulation of mitochondrial structure and functions (Fig. 13, step 
2). On the other hand, TXNIP can directly activate phosphorylation of JNK and promote apoptosis (Fig. 13, step 3). Multiple events induced by IRE1 $\alpha$ inhibitors including BIM activation, mitochondrial membrane depolarization, and caspase 3 activation lead to pancreatic cancer cell death. Our findings indicate that selective inhibition of ER stress by IRE1 $\alpha$ inhibitors may have a therapeutic role in the management of pancreatic cancer.

\section{METHODS}

\section{Cell lines and cell culture}

Pancreatic cancer cell lines (Panc1, Panc0203, Panc0327, Panc0403, Panc0813, Panc1005, AsPc1, BxPc3, MiaPaCa2, PL45, SU8686) were obtained from ATCC (Manassas, VA). They were cultured in RPMI1640 supplemented with $10 \%$ fetal bovine serum and

A

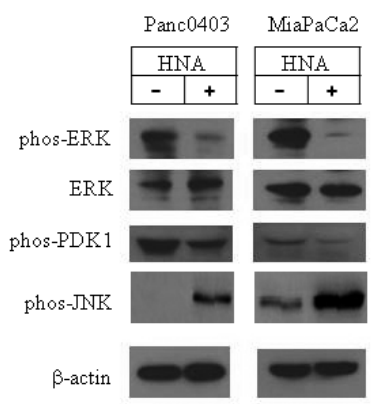

B

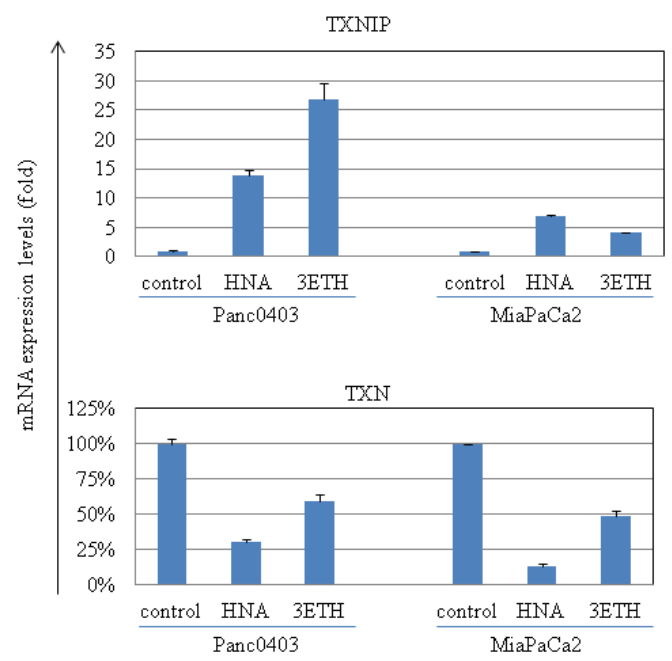

Figure 12: Protein and RNA expression profiles of pancreatic cancer cell lines after treatment with HNA and 3ETH. (A) Western blot analysis of 2 pancreatic cancer cell lines treated with HNA $(10 \mu \mathrm{M}, 24 \mathrm{hr})$. Antibodies used were phos-Erk (phosphorylated Erk), total Erk, phos-PDK and phospJNK. Beta-actin served as loading control. (B) Expression levels of TXNIP (thioredoxin binding protein) and TXN (thioredoxin) mRNA in Panc0403 and MiaCaPa2 cells after HNA and 3ETH treatment $(1 \mu \mathrm{M}, 24 \mathrm{hr})$ by real-time PCR. Results are mean \pm $\mathrm{SD}$ of two independent experiments done in triplicates. maintained at $5 \% \mathrm{CO}_{2}$ and $37^{\circ} \mathrm{C}$. For induction of hypoxia, cells were incubated in temperature-controlled hypoxic culture chamber at $1 \% \mathrm{O}_{2}, 5 \% \mathrm{CO}_{2}$, and $94 \% \mathrm{~N}_{2}$.

\section{MTT assays}

Three thousand cells were seeded in 96-well plates overnight and drug treatment started the next day. After an incubation period, MTT (3-(4,5-dimethylthiazol-2yl)-2,5-diphenyltetrazolium bromide) was added to cells and cultured at $37^{\circ} \mathrm{C}$ for $4 \mathrm{hr}$ followed by stop solution (4 mM HCl, 0.1\% Nondet P40 in isopropanol) which was added to dissolve MTT. The plates were read with a spectrophotometer at $590 \mathrm{~nm}$ absorbance with reference at $630 \mathrm{~nm}$. IC50 values were calculated using GraphPad Prism (La Jolla, CA).

\section{Colony formation assays}

For colony formation on plastic, 800 cells were seeded in 6-well plates overnight, and drugs were applied

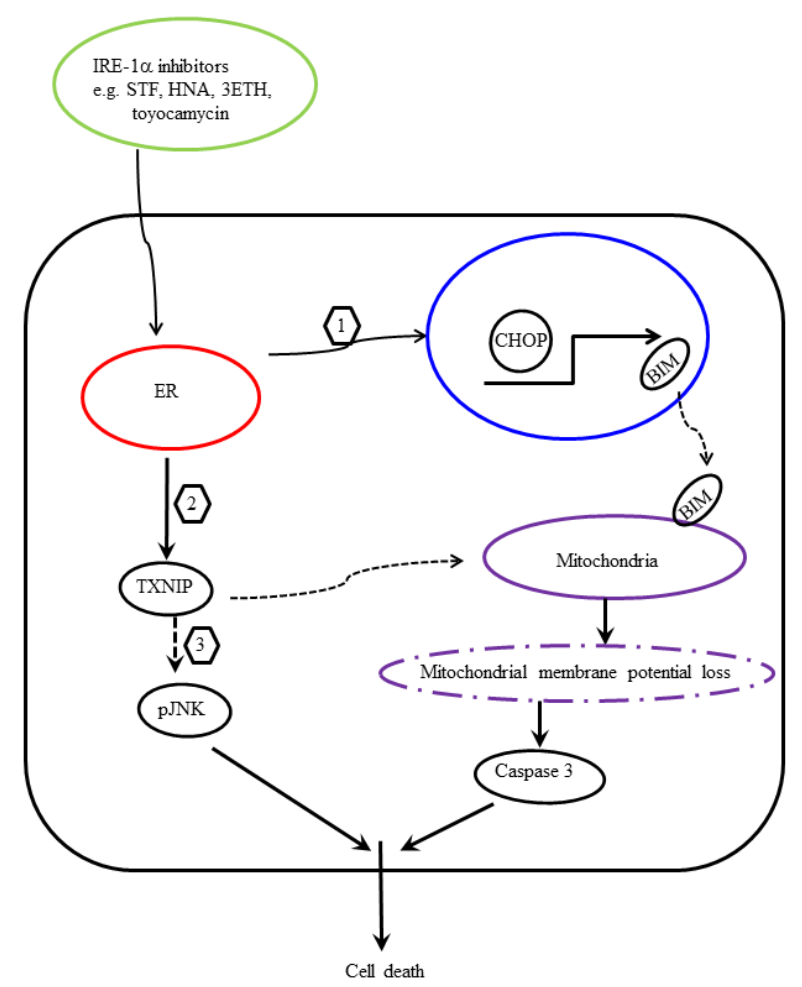

Figure 13: Proposed scheme of IRE1 $\alpha$-induced pancreatic cancer cell death. Treatment of pancreatic cancer cells with IRE1 $\alpha$ inhibitors enhances ER stress and (1) activates $\mathrm{CHOP}$ transcription, which in turn transactivates BIM. Translocation of BIM to mitochondria enhances apopotosis. (2) Modulation of ROS by ER stress up-regulates TXNIP, which causes loss of mitochondrial membrane potential and activates caspase 3 and apoptosis. (3) In addition, TXNIP activates JNK phosphorylation and promotes apoptosis. 
to the cultured cells on the second day. After 14 days, culture medium was removed, and cells were briefly rinsed with PBS. Colonies were stained with crystal violet $(0.2 \%)$. For clonogenic growth in soft agar, 3,000 or 5,000 cells/well in 6 -well plates were cultured in $0.35 \%$ low melting agarose either with or without drugs on top of a bottom layer of $0.5 \%$ agarose. Cells were cultured for either 14 days or when the colonies were large enough for enumeration. Colonies were stained with 1:50 Gentin Violet for $20 \mathrm{~min}$ and rinsed with PBS until the colonies were easily detected. Colonies were photographed and counted with ImageJ (http://rsbweb.nih.gov).

\section{Animal studies}

$\mathrm{BxPc} 3$ pancreatic cancer cells $\left(2 \times 10^{6}\right.$ cells $/ 100$ $\mu 1)$ mixed with matrigel at $1: 1$ ratio were injected subcutaneously into both flanks of NOD/SCID mice. Drug treatment was started four days later. Drug (3ETH) or control diluent (PBS) was injected intraperitoneally three times a week for a total of four weeks. Weight and size were measured after harvesting the tumors.

\section{Studies of drug combination}

Results from MTT assays of different combinations of drugs were analyzed by Calcusyn (Biosoft, UK) for cumulative effects as expressed by isobolograms. An isobologram is a graph indicating the equipotent combinations of different doses of two drugs. Isobologram can clearly show additive, synergistic, or antagonistic effects at different dose levels. A combination index (CI) plot is a Fa-CI plot in which $\mathrm{CI}<1,=1,>1$ indicate synergism, additive effect, and antagonism, respectively. Fa: the fraction that is inhibited by the drug.[43]

\section{Cell cycle analysis}

After drug treatment, cells $\left(1 \times 10^{6} / \mathrm{ml}\right)$ were fixed with $70 \%$ ethanol at $-20^{\circ} \mathrm{C}$ for $30 \mathrm{~min}$. Cells were washed with PBS three times and stained with $40 \mathrm{ug} / \mathrm{ml}$ propidium iodide containing $500 \mathrm{ng} / \mathrm{ml}$ RNase A. Ten thousand events per sample were acquired on LCRII (BD Biosciences, Franklin Lakes, NJ) and analyzed with FlowJo software (Ashland, OR).

\section{Mitochodrial membrane potential analysis}

Binding and accumulation of TMRE (tetramethyrhodamine ethyl ester percholarte) in mitochondria is driven by mitochondrial membrane potential. Depolarization of mitochondria membrane potential leads to loss of TMRE accumulation and decrease in TMRE staining. Mitochondrial membrane potential assessment kit (SeroTec, Oxford, UK) was used following manufacturer's instruction. Membrane potential was measured at $488 \mathrm{~nm}$ excitation and $670 \mathrm{~nm}$ emission with either flow cytometer or fluorescent plate reader. Pancreatic cancer cells [Panc1 $\left(1 \times 10^{6}\right)$ ] seeded in $10-\mathrm{cm}$ dishes overnight, and then were treated with $\operatorname{HNA}(0,1,10$ $\mu \mathrm{M})$ for $24 \mathrm{hr}$. After drug treatment, cells were trypsinized, re-suspended in TMRE working solution to a density of $1 \times 10^{6}$ cells $/ \mathrm{ml}$, and incubated for 20 minutes in a $37^{\circ} \mathrm{C}$ $\mathrm{CO}_{2}$ incubator. After incubation, cells were analyzed with flow cytometry. Histograms measured the proportion of mitochondria that were depolarized as indicated by a decrease in fluorescence. Three pancreatic cancer cell lines (Panc1, Panc0327, Panc0403) plated in 96-well plates were treated with drugs for $24 \mathrm{hr}$, and mitochondrial membrane potential was measured with a fluorescent plate reader. Loss of membrane potential was detected by comparing the fluorescence against the average $575 \mathrm{~nm}$ fluorescence signal in cells.

\section{Western blot analysis}

Following drug treatment, cells were directly lyzed with lysis buffer (Thermo Fisher Scientific, Waltham, MA) containing a protease inhibitor cocktail (Millipore, Billerica, MA) and scraped off of the culture dishes. After 10 min incubation on ice, the lysates were centrifuged at $10,000 \mathrm{xg}$ for $10 \mathrm{~min}$ at $4^{\circ} \mathrm{C}$. Total protein concentration from the supernatants was determined by BCA assay (BioRad Laboratories, Hercules, CA). Thirty micrograms of protein were resolved on SDS-PAGE followed by transfer to PVDF (Millipore). Membranes were blocked with 5\% non-fat milk and incubated with antibodies. Antibodies were from Santa Cruz (Santa Cruz, CA), Cell Signaling (Boston, MA), Sigma Aldrich (St. Louis, MO). ECL reagents (GE Healthcare Life Sciences, Uppsala, Sweden) were used to detect the proteins.

\section{ACKNOWLEDGEMENTS}

This work was funded by the Singapore Ministry of Health's National Medical Research Council (NMRC) under its Singapore Translational Research (STaR) Investigator Award to H. Phillip Koeffler, the National Research Foundation Singapore and the Singapore Ministry of Education under its Research Centres of Excellence initiative, and NIH grants 2R01CA026038-32. We would like to thank Marcia and Jeff Green for their generous support for our pancreatic cancer research.

\section{REFERENCES}

1. Siegel R, Naishadham D and Jemal A. Cancer statistics, 2013. CA: A Cancer Journal for Clinicians. 2013; 63(1):1130. 
2. Erkan M R-EC, Michalski CW, Kong B, Esposito I, Friess H, Kleeff J. The Impact of the Activated Stroma on Pancreatic Ductal Adenocarcinoma Biology and Therapy Resistance. Current Molecular Medicine. 2012; 12(3):16.

3. Di Marco M, Di Cicilia, R., Macchini, M., Nobili, E., Vecchiarelli, S., Brandi, G., \& Biasco, G. Metastatic pancreatic cancer: Is gemcitabine still the best standard treatment? (Review). Oncology Reports. 2010; 23(5):10.

4. Burris H SA. Assessing clinical benefit in the treatment of pancreas cancer: gemcitabine compared to 5-fluorouracil. Eur J Cancer. 1997; 33 (Suppl 1):5.

5. Michaelson MD, Zhu AX, Ryan DP, McDermott DF, Shapiro GI, Tye L, Chen I, Stephenson P, Patyna S, RuizGarcia A and Schwarzberg AB. Sunitinib in combination with gemcitabine for advanced solid tumours: a phase I dose-finding study. Br J Cancer. 2013; 108(7):1393-1401.

6. Mukherjee S, Hurt CN, Bridgewater J, Falk S, Cummins S, Wasan H, Crosby T, Jephcott C, Roy R, Radhakrishna G, McDonald A, Ray R, Joseph G, Staffurth J, Abrams RA, Griffiths G, et al. Gemcitabine-based or capecitabine-based chemoradiotherapy for locally advanced pancreatic cancer (SCALOP): a multicentre, randomised, phase 2 trial. The Lancet Oncology. 2013; 14(4):317-326.

7. Conroy T, Desseigne F, Ychou M, Bouché O, Guimbaud R, Bécouarn Y, Adenis A, Raoul J-L, Gourgou-Bourgade $\mathrm{S}$, de la Fouchardière $\mathrm{C}$, Bennouna $\mathrm{J}$, Bachet $\mathrm{J}-\mathrm{B}$, Khemissa-Akouz F, Péré-Vergé D, Delbaldo C, Assenat E, et al. FOLFIRINOX versus Gemcitabine for Metastatic Pancreatic Cancer. New England Journal of Medicine. 2011; 364(19):1817-1825.

8. Moore KA and Hollien J. The Unfolded Protein Response in Secretory Cell Function. Annual Review of Genetics. 2012; 46(1):165-183.

9. Daneshmand S, Quek ML, Lin E, Lee C, Cote RJ, Hawes D, Cai J, Groshen S, Lieskovsky G, Skinner DG, Lee AS and Pinski J. Glucose-regulated protein GRP78 is upregulated in prostate cancer and correlates with recurrence and survival. Human Pathology. 2007; 38(10):1547-1552.

10. Zheng H-c, Takahashi H, Li X-h, Hara T, Masuda S, Guan Y-f and Takano Y. Overexpression of GRP78 and GRP94 are markers for aggressive behavior and poor prognosis in gastric carcinomas. Human Pathology. 2008; 39(7):10421049.

11. Györffy B, Lanczky A, Eklund A, Denkert C, Budczies J, Li $\mathrm{Q}$ and Szallasi Z. An online survival analysis tool to rapidly assess the effect of 22,277 genes on breast cancer prognosis using microarray data of 1,809 patients. Breast Cancer Res Treat. 2010; 123(3):725-731.

12. Shore GC, Papa FR and Oakes SA. Signaling cell death from the endoplasmic reticulum stress response. Current Opinion in Cell Biology. 2011; 23(2):143-149.

13. Yamaguchi $\mathrm{H}$ and Wang $\mathrm{H}-\mathrm{G}$. CHOP Is Involved in Endoplasmic Reticulum Stress-induced Apoptosis by Enhancing DR5 Expression in Human Carcinoma Cells.
Journal of Biological Chemistry. 2004; 279(44):4549545502.

14. Vasseur S, Tomasini R, Tournaire R and Iovanna JL. Hypoxia Induced Tumor Metabolic Switch Contributes to Pancreatic Cancer Aggressiveness. Cancers. 2010; 2(4):2138-2152.

15. Siegelin MD. Utilization of the cellular stress response to sensitize cancer cells to TRAIL-mediated apoptosis. Expert Opinion on Therapeutic Targets. 2012; 16(8):801-817.

16. Atkins C, Liu Q, Minthorn E, Zhang S-Y, Figueroa DJ, Moss K, Stanley TB, Sanders B, Goetz A, Gaul N, Choudhry AE, Alsaid H, Jucker BM, Axten JM and Kumar R. Characterization of a Novel PERK Kinase Inhibitor with Antitumor and Antiangiogenic Activity. Cancer Research. 2013; 73(6):1993-2002.

17. Hetz C, Chevet E and Harding HP. Targeting the unfolded protein response in disease. Nat Rev Drug Discov. 2013; 12(9):703-719.

18. Ma X-H, Piao S-F, Dey S, McAfee Q, Karakousis G, Villanueva J, Hart LS, Levi S, Hu J, Zhang G, Lazova R, Klump V, Pawelek JM, Xu X, Xu W, Schuchter LM, et al. Targeting ER stress-induced autophagy overcomes BRAF inhibitor resistance in melanoma. The Journal of Clinical Investigation. 2014; 124(3):1406-1417.

19. Chiu CC, Lee LY, Li YC, Chen YJ, Lu YC, Li YL, Wang HM, Chang JT and Cheng AJ. Grp78 as a therapeutic target for refractory head-neck cancer with CD24-CD44+ stemness phenotype. Cancer Gene Ther. 2013; 20(11):606615.

20. Ling SCW, Lau EKK, Al-Shabeeb A, Nikolic A, Catalano A, Iland H, Horvath N, Ho PJ, Harrison S, Fleming S, Joshua DE and Allen JD. Response of myeloma to the proteasome inhibitor bortezomib is correlated with the unfolded protein response regulator XBP-1. Haematologica. 2012; 97(1):64-72.

21. Gambella M, Rocci A, Passera R, Gay F, Omedè P, Crippa C, Corradini P, Romano A, Rossi D, Ladetto M, Boccadoro $\mathrm{M}$ and Palumbo A. High XBP1 expression is a marker of better outcome in multiple myeloma patients treated with bortezomib. Haematologica. 2014; 99(2):e14-e16.

22. Nawrocki ST, Carew JS, Pino MS, Highshaw RA, Dunner K, Huang P, Abbruzzese JL and McConkey DJ. Bortezomib Sensitizes Pancreatic Cancer Cells to Endoplasmic Reticulum Stress-Mediated Apoptosis. Cancer Research. 2005; 65(24):11658-11666.

23. Nawrocki ST, Carew JS, Dunner K, Boise LH, Chiao PJ, Huang P, Abbruzzese JL and McConkey DJ. Bortezomib Inhibits PKR-Like Endoplasmic Reticulum (ER) Kinase and Induces Apoptosis via ER Stress in Human Pancreatic Cancer Cells. Cancer Research. 2005; 65(24):11510-11519.

24. Kriss CL, Pinilla-Ibarz JA, Mailloux AW, Powers JJ, Tang C-HA, Kang CW, Zanesi N, Epling-Burnette PK, Sotomayor EM, Croce CM, Del Valle JR and Hu C-CA. Overexpression of TCL1 activates the endoplasmic 
reticulum stress response: a novel mechanism of leukemic progression in mice. Blood. 2012; 120(5):1027-1038.

25. Ri M TE, Oikawa D, Shinjo S, Tokuda M, Yokouchi Y, Narita T, Masaki A, Ito A, Ding J, Kusumoto S, Ishida T, Komatsu H, Shiotsu Y, Ueda R, Iwawaki T, Imoto M, Iida $\mathrm{S}$. Identification of Toyocamycin, an agent cytotoxic for multiple myeloma cells, as a potent inhibitor of ER stressinduced XBP1 mRNA splicing. Blood Cancer Journal. 2012; 2(7):11.

26. Volkmann K, Lucas JL, Vuga D, Wang X, Brumm D, Stiles C, Kriebel D, Der-Sarkissian A, Krishnan K, Schweitzer C, Liu Z, Malyankar UM, Chiovitti D, Canny M, Durocher $\mathrm{D}$, Sicheri F, et al. Potent and Selective Inhibitors of the Inositol-requiring Enzyme 1 Endoribonuclease. Journal of Biological Chemistry. 2011; 286(14):12743-12755.

27. Puthalakath H, O'Reilly LA, Gunn P, Lee L, Kelly PN, Huntington ND, Hughes PD, Michalak EM, McKimmBreschkin J, Motoyama N, Gotoh T, Akira S, Bouillet P and Strasser A. ER Stress Triggers Apoptosis by Activating BH3-Only Protein Bim. Cell. 2007; 129(7):1337-1349.

28. Lee A-H, Iwakoshi NN and Glimcher LH. XBP-1 Regulates a Subset of Endoplasmic Reticulum Resident Chaperone Genes in the Unfolded Protein Response. Molecular and Cellular Biology. 2003; 23(21):7448-7459.

29. Montalbano R WP, Quint K, Jabari S, Neureiter D, Illig R, Ocker M, Di Fazio P. Endoplasmic Reticulum Stress Plays a Pivotal Role in Cell Death Mediated by the Pan-Deacetylase Inhibitor Panobinostat in Human Hepatocellular Cancer Cells. Translational Oncology. 2013; 6(2):15.

30. Carew JS, Nawrocki ST, Krupnik YV, Dunner K, McConkey DJ, Keating MJ and Huang P. Targeting endoplasmic reticulum protein transport: a novel strategy to kill malignant B cells and overcome fludarabine resistance in CLL. Blood. 2006; 107(1):222-231.

31. Calfon M, Zeng H, Urano F, Till JH, Hubbard SR, Harding HP, Clark SG and Ron D. IRE1 couples endoplasmic reticulum load to secretory capacity by processing the XBP1 mRNA. Nature. 2002; 415(6867):92-96.

32. Ewings KE WC, Cook SJ. Bim and the Pro-Survival Bcl-2 Proteins: Opposites Attract, ERK Repels. . Cell Cycle 2007; 6:5.

33. Luciano F, Jacquel A, Colosetti P, Herrant M, Cagnol S, Pages G and Auberger P. Phosphorylation of Bim-EL by Erk1//2 on serine 69 promotes its degradation via the proteasome pathway and regulates its proapoptotic function. Oncogene. 2003; 22(43):6785-6793.

34. Harada H, Quearry B, Ruiz-Vela A and Korsmeyer SJ. Survival factor-induced extracellular signal-regulated kinase phosphorylates BIM, inhibiting its association with BAX and proapoptotic activity. Proceedings of the National Academy of Sciences of the United States of America. 2004; 101(43):15313-15317.

35. Lei K and Davis RJ. JNK phosphorylation of Bim-related members of the $\mathrm{Bcl} 2$ family induces Bax-dependent apoptosis. Proceedings of the National Academy of Sciences. 2003; 100(5):2432-2437.

36. Kim I, Xu W and Reed JC. Cell death and endoplasmic reticulum stress: disease relevance and therapeutic opportunities. Nat Rev Drug Discov. 2008; 7(12):10131030.

37. Li H, Chang G, Wang J, Wang L, Jin W, Lin Y, Yan Y, Wang R, Gao W, Ma L, Li Q and Pang T. Cariporide Sensitizes Leukemic Cells to TRAIL by Up-regulation of Death Receptor 5 via ER stress- CHOP dependent Mechanism. Leukemia \& Lymphoma. 2013:1-14.

38. Gottlieb E, Armour SM, Harris MH and Thompson CB. Mitochondrial membrane potential regulates matrix configuration and cytochrome c release during apoptosis. Cell Death Differ. 2003; 10(6):709-717.

39. Zhou J and Chng W-J. Roles of thioredoxin binding protein (TXNIP) in oxidative stress, apoptosis and cancer. Mitochondrion. 2013; 13(3):163-169.

40. Hamilton JP, Potter JJ, Koganti L, Meltzer SJ and Mezey E. Effects of Vitamin D3 stimulation of Thioredoxin Interacting Protein in hepatocellular carcinoma. Hepatology Research. 2014:doi: 10.1111/hepr.12302.

41. Slavica Brnjic MM, Mårten Fryknäs, Chao Sun, Xiaonan Zhang, Rolf Larsson, Pádraig D’Arcy, and Stig Linder. Induction of Tumor Cell Apoptosis by a Proteasome Deubiquitinase Inhibitor Is Associated with Oxidative Stress Antioxidants \& Redox Signaling. 2013.

42. Lee S-O, Jin U-H, Kang JH, Kim SB, Guthrie AS, Sreevalsan S, Lee J-S and Safe S. The Orphan Nuclear Receptor NR4A1 (Nur77) Regulates Oxidative and Endoplasmic Reticulum Stress in Pancreatic Cancer Cells. Molecular Cancer Research. 2014.

43. Chou T-C. Theoretical Basis, Experimental Design, and Computerized Simulation of Synergism and Antagonism in Drug Combination Studies. PHARMACOLOGICAL REVIEWS. 2006; 58:61. 